\title{
Safety profile and clinical activity of multiple subcutaneous doses of MEDI-528, a humanized anti-interleukin-9 monoclonal antibody, in two randomized phase $2 a$ studies in subjects with asthma
}

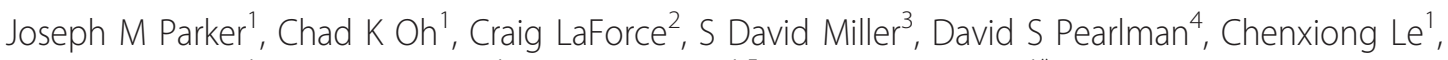 \\ Gabriel J Robbie ${ }^{1}$, Wendy I White ${ }^{1}$, Barbara White ${ }^{1,5}$, Nestor A Molfino ${ }^{1 *}$, the MEDI-528 Clinical Trials Group
}

\begin{abstract}
Background: Interleukin-9 (IL-9)-targeted therapies may offer a novel approach for treating asthmatics. Two randomized placebo-controlled studies were conducted to assess the safety profile and potential efficacy of multiple subcutaneous doses of MEDI-528, a humanized anti-IL-9 monoclonal antibody, in asthmatics.

Methods: Study 1: adults (18-65 years) with mild asthma received MEDI-528 $(0.3,1,3 \mathrm{mg} / \mathrm{kg})$ or placebo subcutaneously twice weekly for 4 weeks. Study 2: adults (18-50 years) with stable, mild to moderate asthma and exercise-induced bronchoconstriction received $50 \mathrm{mg}$ MEDI-528 or placebo subcutaneously twice weekly for 4 weeks. Adverse events (AEs), pharmacokinetics (PK), immunogenicity, asthma control (including asthma exacerbations), and exercise challenge test were evaluated in study 1, study 2, or both.

Results: In study $1(\mathrm{~N}=36)$, MEDI-528 showed linear serum PK; no anti-MEDI-528 antibodies were detected. Asthma control: 1/27 MEDI-528-treated subjects had 1 asthma exacerbation, and 2/9 placebo-treated subjects had a total of 4 asthma exacerbations (one considered a serious AE). In study 2, MEDI-528 ( $n=7)$ elicited a trend in the reduction in mean maximum decrease in $\mathrm{FEV}_{1}$ post-exercise compared to placebo $(n=2)(-6.49 \%$ MEDI-528 vs $-12.60 \%$ placebo; $-1.40 \%$ vs $-20.10 \% ;-5.04 \%$ vs $-15.20 \%$ at study days 28,56 , and 150 , respectively). Study 2 was halted prematurely due to a serious AE in an asymptomatic MEDI-528-treated subject who had an abnormal brain magnetic resonance imaging that was found to be an artifact on further evaluation.
\end{abstract}

Conclusions: In these studies, MEDI-528 showed an acceptable safety profile and findings suggestive of clinical activity that support continued study in subjects with mild to moderate asthma.

Trial registration: ClinicalTrials (NCT): NCT00507130 and ClinicalTrials (NCT): NCT00590720

\section{Background}

Asthma continues to be a significant health problem [1], with nearly $8 \%$ of the US population reported to have asthma in 2006 [2]. In one study, approximately $30 \%$ of $>3,400$ asthmatics failed to achieve control despite regular use of combination therapy with high-dose inhaled corticosteroids (ICS) and long-acting $\beta_{2}$-agonists [3].

\footnotetext{
* Correspondence: molfinon@medimmune.com

'Medlmmune, LLC, Gaithersburg, MD, USA

Full list of author information is available at the end of the article
}

Interleukin (IL)-9, a 144 amino acid-long protein secreted by $\mathrm{CD}_{4}^{+} \mathrm{T}$-helper 2 (Th2) cells, mast cells, eosinophils, and neutrophils [4-7], may be associated with airway hyperresponsiveness (AHR) and inflammation [8-11]. Evidence supporting IL-9 as a potential target treatment for asthma emerged from a series of genetic experiments linking AHR to a region on chromosome 13 in mice, which contains the IL-9 gene and is syntenic with the $5 \mathrm{q} 31-\mathrm{q} 33$ chromosome in humans [8]. 
Overexpression of IL-9 in murine models of asthma has been shown to cause airway inflammation with pulmonary infiltration of eosinophils and lymphocytes, airway obstruction, and mast cell hyperplasia $[9,10,12]$. In contrast, anti-IL-9 antibody therapy has led to reduced levels of AHR in murine models of allergen-induced asthma $[13,14]$.

Blocking IL-9 expression inhibits airway inflammation in a mast cell-dependent murine model of asthma. Mast cell-deficient animals demonstrated reduced lung inflammation and AHR compared with wild-type control mice [15]. An IL-9-neutralizing monoclonal antibody effectively reduced lung recovery of mast cell precursors and inflammatory cells after allergen challenge [16]. These findings suggest that IL-9 promotes asthma pathology in a mast cell-dependent manner through the proliferation of mast cell precursors or the recruitment of immature mast cells to lung tissue, or both.

Mast cell degranulation and release of spasmogenic mediators have been reported to cause bronchoconstriction in subjects with exercise-induced asthma $[17,18]$. Exercise challenge is an indirect airway challenge that results in airway narrowing due to the release of mediators from mast cell degranulation, as opposed to direct airway challenges such as methacholine that act directly on the airway smooth muscle to produce bronchoconstriction [19].

Additionally, in asthmatics, bronchial biopsy specimens revealed increased IL-9 immunoreactive cells and IL-9 mRNA, protein, and receptor levels compared with those of healthy controls [20-23]. These data suggest that IL-9-targeted therapies may offer a novel approach for treating patients with asthma and may reduce exercise-induced bronchoconstriction (EIB).

MEDI-528 is a humanized anti-IL-9 monoclonal antibody. Results from 2 open-label, phase 1 studies demonstrated that MEDI-528, administered as a single intravenous or subcutaneous (SC) dose, had an acceptable safety profile in healthy volunteers, with no serious adverse events (AEs) and a linear pharmacokinetic (PK) profile [24].

We report the results of 2 studies evaluating the safety, tolerability, PK, and immunogenicity profiles of multiple SC doses of MEDI-528, and the potential reduction of EIB in subjects with mild to moderate asthma. Study 2 was halted prematurely due to a serious $\mathrm{AE}$ (SAE) in an asymptomatic MEDI-528-treated subject who had an abnormal brain magnetic resonance imaging (MRI) that was found to be an artifact on further evaluation.

\section{Methods}

\section{Subjects}

Adults aged 18-65 years with mild persistent asthma (forced expiratory volume in 1 second $\left[\mathrm{FEV}_{1}\right]$ or peak expiratory flow $[\mathrm{PEF}] \geq 80 \%$ of predicted) receiving therapy with short-acting $\beta_{2}$-agonists (SABA), inhaled corticosteroids (ICS) $<264 \mu \mathrm{g} /$ day fluticasone or equivalent, or both (study 1) and adults aged 18-50 years with stable mild to moderate persistent asthma receiving therapy with SABA, ICS $<800 \mu \mathrm{g} /$ day budesonide or equivalent, and EIB (decrease in $\mathrm{FEV}_{1}$ of $\geq 15 \%$ from baseline during screening) (study 2) were eligible [25].

Exclusion criteria included lung disease other than asthma, use of systemic immunosuppressive drugs, and smoking history $\geq 10$ pack-years. Long-acting $\beta_{2}$-agonists, cromolyn sodium, nedocromil sodium, leukotriene receptor antagonists, theophylline, and omalizumab were not allowed (studies 1 and 2).

\section{Study design}

Study 1 was a randomized, double-blind, placebocontrolled, dose-escalation, multicenter study evaluating the safety, tolerability, $\mathrm{PK}$, and immunogenicity profiles of multiple SC doses of MEDI-528. For each cohort $(0.3 \mathrm{mg} / \mathrm{kg}, 1 \mathrm{mg} / \mathrm{kg}$, or $3 \mathrm{mg} / \mathrm{kg})$, subjects were randomized 3:1 via an interactive voice response system (IVRS) to receive MEDI-528 or placebo as SC injections twice weekly for 4 weeks through study day 24 ; thereafter, subjects were monitored for 126 days. Dosing at each next higher dose group commenced after all evaluable subjects from the previous lower dose group completed evaluations on study day 56 with acceptable safety profiles. Subjects who received $\geq 7$ doses of the study drug were considered evaluable. Those not evaluable were replaced, unless they withdrew from the study due to safety reasons. The primary outcome for this study was the safety and tolerability of multiple SC doses of MEDI-528. Secondary outcomes included PK and immunogenecity of MEDI-528 in this subject population. Exploratory outcomes included effects of MEDI528 on pulmonary function, asthma exacerbations, symptoms, rescue SABA use, and quality of life.

Study 2 was a randomized, double-blind, placebocontrolled, multicenter study evaluating the safety and tolerability profiles of multiple SC doses of MEDI-528 in three cohorts of 50,100, and $200 \mathrm{mg}$ versus placebo. Subjects were randomized 2:1 via IVRS to receive MEDI-528 or placebo as an SC injection twice weekly for 4 weeks; thereafter, subjects were monitored for 126 days. Subjects who received $\geq 4$ doses of study drug (unless they discontinued for safety reasons) and had $\geq 2$ exercise challenge tests (baseline and post-therapy) were considered evaluable. The primary outcome of this study was the safety and tolerability of multiple SC doses of MEDI-528 in adult subjects with stable asthma and EIB. Secondary objectives included the effect of MEDI-528 on EIB and immunogenicity. Exploratory outcomes included the effects of MEDI-528 on 
spirometry, airway hyperresponsiveness as measured by methacholine challenge testing, asthma exacerbations, asthma symptoms, rescue SABA use, quality of life, and nasal allergy symptoms in this population.

In both studies, all subjects and protocol-associated personnel were blinded to the individual subject treatment assignment until the last subject in each cohort completed the study and the databases were locked.

Both studies were conducted in accordance with the Declaration of Helsinki and were approved by an institutional review board/independent ethics committee at each participating site. Written informed consent was obtained from each subject before study entry.

\section{Safety profile}

In both studies, AEs and SAEs were monitored after the first dose through day 150. AEs were graded by severity (mild, moderate, severe) and relationship to study drug (none, remote, possible, probable, definite) as determined by each investigator. Other safety measures included routine laboratory tests, vital signs, electrocardiograms (ECGs), and physical examinations. Physical examination included assessments for splenomegaly (palpable spleen), lymphadenopathy, and neurologic abnormalities.

In both studies, a noncontrast MRI of the brain was performed at screening and day 28. MRI was added to the current studies and other MEDI-528 studies [24] based on preclinical toxicology findings of lymphohistiocytic perivascular infiltrates in the brains of cynomolgus monkeys seen in both treated and control animals. The study and peer-review pathologists considered this a spontaneous background finding unrelated to treatment. Subsequent MEDI-528 toxicology studies in monkeys and of MM9C1 in mice found no evidence of macroscopic or microscopic pathologic changes in the brain; MRI is therefore not required for subsequent clinical studies of MEDI-528 (data on file, MedImmune, LLC).

Subjects in both studies who received any dose of study drug were included in the safety analyses.

\section{Pharmacokinetics and immunogenicity}

In study 1, blood samples for measuring serum concentrations of MEDI-528 were collected before dosing and at specified times throughout the study. As previously described [24], a validated enzyme-linked immunosorbent assay (ELISA) was used for these measurements. Unknown values with calculated concentrations below the assay's lower limit of quantitation $(<1.25 \mu \mathrm{g} / \mathrm{mL})$ were reported as less than the limit of quantitation.

A double-antigen sandwich ELISA was performed to evaluate anti-MEDI-528 antibodies [24].

\section{Excercise challenge test}

In study 2, exercise challenge was performed at baseline prior to dosing and on study days 28, 56, and 150 after dosing [26]. A response to therapy was defined as a maximum decrease in post-exercise $\mathrm{FEV}_{1}$ of $<10 \%$, based on American Thoracic Society guidelines [27]. Spirometry was performed 15 minutes before initiation of the treadmill test and 5, 10, 15, 20, and 30 minutes after the treadmill test was completed. At each time point, maximum $\mathrm{FEV}_{1}$ was determined. The decrease in $\mathrm{FEV}_{1}$ at each time point after the treadmill test was calculated as a percentage of the best baseline $\mathrm{FEV}_{1}$.

\section{Asthma control and quality of life}

In both studies, an asthma exacerbation was defined as a worsening of asthma requiring oral corticosteroids, a doubling of the ICS dose from baseline, hospitalization, emergency department visit, or an unscheduled asthmarelated visit to a health care provider. Asthma symptom scores were recorded twice daily for the duration of the study. Symptoms were assessed on a scale of 0 (no symptoms) to 4 (marked discomfort). Rescue SABA use (puffs/day) was recorded daily by subjects for the duration of the study. Subjects completed the Asthma Quality of Life Questionnaire (AQLQ) [28] at baseline and after dosing.

\section{Additional evaluations}

Skin prick testing of common food and aeroallergens was performed during screening for both studies and on study day 28 for study 1 [29]. In both studies, spirometry was performed according to existing guidelines [30].

\section{Statistical analyses}

Formal sample size calculations were not applicable for assessment of the primary objective (safety/tolerability profile). No statistical hypothesis testing was performed for this end point. Data analyses were conducted using the SAS System (SAS Institute Inc., Cary, NC).

AEs and SAEs were described using the MedDRA Adverse Event Thesaurus by system organ class, severity, and relationship to study drug through 18 weeks after the last dose (day 150). Laboratory values with a higher toxicity grade than that observed at baseline were recorded as AEs. The day 0 value before study drug administration was used as a baseline for laboratory parameters. Study discontinuation blood samples were summarized at the closest nominal time point that did not already have a value.

The original design for study 2 included 3 cohorts (50 mg, $100 \mathrm{mg}$, and $200 \mathrm{mg}$ MEDI-528), each with 18 subjects randomized 2:1 to receive MEDI-528 or placebo. Sample size calculations were based on two-sample $t$ test of the reduction in the maximum decline of $\mathrm{FEV}_{1}$ after 
exercise challenge testing. The power to detect a statistically significant difference in the maximum decline in $\mathrm{FEV}_{1}$ was greater than $80 \%$ based on an assumption of a $20 \%$ fall in the placebo group and $65 \%$ reduction in the maximum decline of $\mathrm{FEV}_{1}$ in the combined group (36 subjects) on active treatment versus placebo (18 subjects).

Serum concentrations and PK parameters were analyzed using WinNonlin (Pharsight, St. Louis, MO) and descriptive statistics summarized for each MEDI-528 treatment group. The number of subjects exhibiting anti-MEDI-528 antibodies was summarized, and all valid assay results from subjects who received any study drug were included in immunogenicity summaries.

No formal statistical hypothesis tests were conducted for exploratory variables (pulmonary function, asthma exacerbations, symptom scores, rescue SABA use, quality of life). These variables were examined for their medical/clinical implications.
Two-sample $t$ tests were used to explore the change from baseline in $\mathrm{FEV}_{1}$ and asthma symptom score between MEDI-528 and placebo groups. The Fisher exact test was used to explore the difference in asthma exacerbation proportions between the placebo and MEDI-528 groups. The total number of exacerbations per subject during the study was noted.

\section{Results}

\section{Demographics and baseline characteristics}

In study 1,36 subjects were randomized between June 2007 and February 2008 at 8 sites, and 33 completed the study through day 150 . Two MEDI-528-treated subjects were lost to follow-up and 1 placebo-treated subject withdrew due to an asthma exacerbation requiring hospitalization. All 36 subjects were evaluable (ie, received $\geq 7$ doses of study drug) and included in the safety analyses (Figure 1A). There were more ex-smokers in the placebo group, otherwise the groups' baseline characteristics were comparable (Table 1).

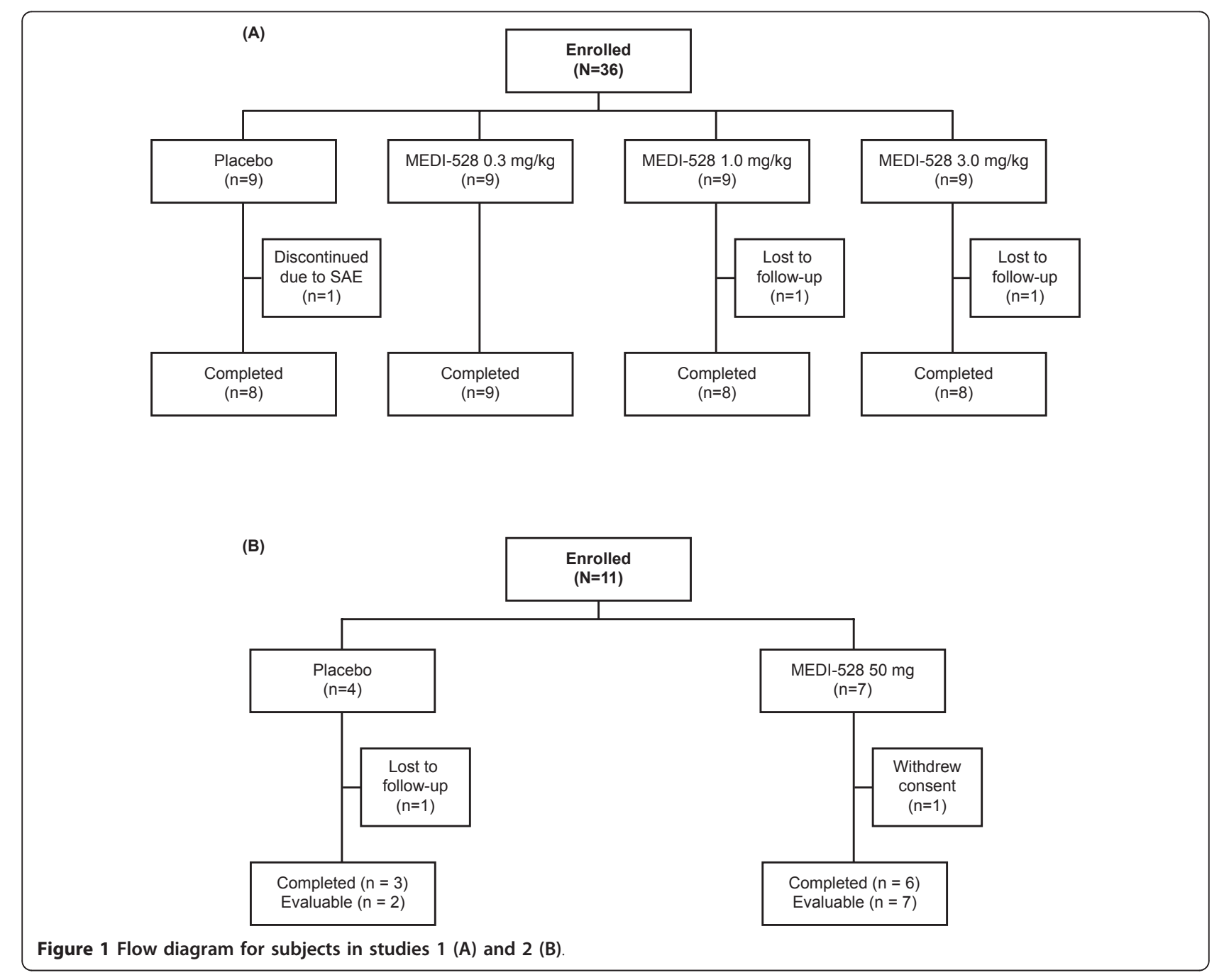




\begin{tabular}{|c|c|c|c|c|c|c|}
\hline \multirow[b]{3}{*}{ Parameter } & \multicolumn{4}{|c|}{ Study 1} & \multicolumn{2}{|c|}{ Study 2} \\
\hline & \multirow[b]{2}{*}{$\begin{array}{c}\text { Placebo } \\
(n=9)\end{array}$} & \multicolumn{3}{|c|}{ MEDI-528 } & \multirow[b]{2}{*}{$\begin{array}{c}\text { Placebo } \\
(n=4)\end{array}$} & \multirow[b]{2}{*}{$\begin{array}{c}\text { MEDI-528 } \\
50 \mathrm{mg}(\mathrm{n}=7)\end{array}$} \\
\hline & & $\begin{array}{c}0.3 \mathrm{mg} / \mathrm{kg} \\
(\mathrm{n}=9)\end{array}$ & $\begin{array}{c}1 \mathrm{mg} / \mathrm{kg} \\
(\mathrm{n}=9)\end{array}$ & $\begin{array}{c}3 \mathrm{mg} / \mathrm{kg} \\
(\mathrm{n}=9)\end{array}$ & & \\
\hline Mean age, years (range) & $38.6(22-63)$ & $38.2(18-61)$ & $33.2(19-57)$ & $28.9(19-55)$ & $31.8(19-47)$ & $32.1(19-39)$ \\
\hline Female, n (\%) & $8(88.9)$ & $8(88.9)$ & $5(55.6)$ & $5(55.6)$ & $2(50)$ & $6(85.7)$ \\
\hline \multicolumn{7}{|l|}{ Race/Ethnicity, n (\%) } \\
\hline White/non-Hispanic & $8(88.9)$ & $6(66.7)$ & $9(100)$ & $5(55.6)$ & $3(75.0)$ & $6(85.7)$ \\
\hline White/Hispanic & $0(0.0)$ & $0(0.0)$ & $0(0.0)$ & $0(0.0)$ & $0(0.0)$ & $1(14.3)$ \\
\hline Black & $0(0.0)$ & $2(22.2)$ & $0(0.0)$ & $3(33.3)$ & $1(25.0)$ & $0(0.0)$ \\
\hline Asian & $0(0.0)$ & $0(0.0)$ & $0(0.0)$ & $1(11.1)$ & $0(0.0)$ & $0(0.0)$ \\
\hline Multiracial & $1(11.1)$ & $1(11.1)$ & $0(0.0)$ & $0(0.0)$ & $0(0.0)$ & $0(0.0)$ \\
\hline Mean weight, kg (range) & $68.5(52.0-93.9)$ & $78.9(58.2-99.7)$ & $72.3(43.0-99.1)$ & $72.7(57.6-97.7)$ & $77.3(57.7-93.2)$ & $73.4(52.7-97.3)$ \\
\hline Mean (SD) FEV $1(L)^{*}$ & $2.8(0.58)$ & $2.8(0.93)$ & $3.2(0.73)$ & $3.4(0.43)$ & $3.3(1.25)$ & $2.8(0.56)$ \\
\hline Ever smoked, n (\%) & $7(77.8)$ & $1(11.1)$ & $1(11.1)$ & $0(0.0)$ & $1(25.0)$ & $2(28.6)$ \\
\hline \multicolumn{7}{|c|}{ Exacerbations in past year, no. (\%) } \\
\hline None & $4(44.4)$ & $6(66.7)$ & $6(66.7)$ & $4(44.4)$ & $2(50.0)$ & $3(42.9)$ \\
\hline $1-2$ & $5(55.6)$ & $3(33.3)$ & $2(22.2)$ & $5(55.6)$ & $2(50.0)$ & $4(57.1)$ \\
\hline $3-5$ & $0(0.0)$ & $0(0.0)$ & $1(11.1)$ & $0(0.0)$ & $0(0.0)$ & $0(0.0)$ \\
\hline
\end{tabular}

*Measurements from evaluable subjects (those who received $\geq 7$ or $\geq 4$ doses of the study drug in study 1 and study 2 , respectively); ITT $=$ intent to treat (all randomized subjects); $\mathrm{SD}=$ standard deviation; $\mathrm{FEV}_{1}=$ forced expiratory volume in 1 second.

In study 2, 11 subjects were randomized and dosed with $50 \mathrm{mg}$ of MEDI-528 or placebo between February and May 2008 at 4 sites, and 9 completed the study through day 150 (Figure 1B). Nine subjects were evaluable (ie, received $\geq 4$ doses of study drug). Two placebotreated subjects were not evaluable (1 received only 2 doses of study drug and 1 was lost to follow-up). All 11 subjects were included in the safety analyses. Baseline characteristics were similar between study groups (Table 1).

\section{Safety profile}

The most frequently reported AEs in study 1 are listed in Table 2. Severe AEs were reported in 4 placebo-treated subjects (vomiting, $\mathrm{n}=1$; elevated lipase, $\mathrm{n}=2$; asthma, $\mathrm{n}=1$ ) and 2 subjects receiving MEDI-528 0.3 $\mathrm{mg} / \mathrm{kg}$ (severe diarrhea, $\mathrm{n}=1$; elevated alanine aminotranferase $[\mathrm{ALT}], \mathrm{n}=1)$. The severe asthma $\mathrm{AE}$ in the 1 placebo-treated subject was an SAE (asthma exacerbation requiring hospitalization); this subject was discontinued from the study. The elevated ALT seen in the MEDI-528-treated subject was noted on the first day of dosing. This subject received no further drug and the elevated levels resolved by study day 42 . No deaths were noted during this study.

Abnormal but clinically nonsignificant ECG results were detected during the study in 5 placebo-treated subjects, 5 subjects in the MEDI-528 $0.3-\mathrm{mg} / \mathrm{kg}$ group, and 2 subjects each in the MEDI-528 1-mg/kg and 3-mg/kg groups. One subject in the MEDI-528 3-mg/kg group exhibited an asymptomatic elevation of troponin levels at a single time point on study day 84 . No significant changes in the central nervous system were observed from the brain MRI or focused neurological examinations.

The most frequently reported AEs in study 2 are listed in Table 3. A total of 5 severe AEs occurred in 4 subjects; 3 placebo-treated subjects had 1 event each (eye infection, cough, drug hypersensitivity) and 1 MEDI-528-treated subject had 2 events (sunburn, back pain). No significant ECG changes occurred and no elevations in troponin levels were observed. One SAE occurred in a MEDI-528-treated subject (abnormal brain MRI results). The subject had a $6-\times 4-\mathrm{mm}$ leftsided pontine hyperintensity noted on the day 28 MRI that was not present at baseline. The investigator considered the event possibly related to study drug, resulting in a clinical hold of the study. A repeat MRI with gadolinium contrast showed no abnormal findings or pontine hyperintensity. Review by an independent neuroradiologist determined the initial MRI finding to be an artifact. The clinical hold was lifted, but the study was discontinued due to the length of the delay.

\section{Pharmacokinetics and immunogenicity}

In study 1 , limited PK parameters were estimable because the dosing interval for MEDI-528 was not constant, alternating between 3 days and 4 days, and PK sampling was sparse.

After the last MEDI-528 dose, maximum serum concentrations were generally achieved between 3 and 4 days across dose levels (Table 4). Mean maximum concentration after the last dose of $0.3 \mathrm{mg} / \mathrm{kg}$ to $3 \mathrm{mg} / \mathrm{kg}$, respectively, 
Table 2 Most Frequently Reported Adverse Events in Study 1 (Safety Population*)

\begin{tabular}{|c|c|c|c|c|c|}
\hline \multirow{3}{*}{ Event } & \multicolumn{5}{|c|}{ No. (\%) of Subjects } \\
\hline & \multirow[b]{2}{*}{$\begin{array}{l}\text { Placebo } \\
(\mathrm{n}=9)\end{array}$} & \multicolumn{4}{|c|}{ MEDI-528 } \\
\hline & & $\begin{array}{c}0.3 \\
\mathrm{mg} / \mathrm{kg} \\
(\mathrm{n}=9)\end{array}$ & $\begin{array}{c}1 \mathrm{mg} / \\
\mathrm{kg} \\
(\mathrm{n}=9)\end{array}$ & $\begin{array}{c}3 \mathrm{mg} / \\
\mathrm{kg} \\
(\mathrm{n}=9)\end{array}$ & $\begin{array}{l}\text { Total } \\
(\mathrm{n}=27)\end{array}$ \\
\hline $\begin{array}{l}\text { Blood glucose } \\
\text { increase }\end{array}$ & $3(33.3)$ & $5(55.6)$ & $2(22.2)$ & $1(11.1)$ & $8(29.6)$ \\
\hline Nasopharyngitis & $4(44.4)$ & $3(33.3)$ & $1(11.1)$ & $2(22.2)$ & $6(22.2)$ \\
\hline $\begin{array}{l}\text { Blood bicarbonate } \\
\text { decrease }\end{array}$ & $1(11.1)$ & $1(11.1)$ & $2(22.2)$ & $3(33.3)$ & $6(22.2)$ \\
\hline Injection site pain & $0(0.0)$ & $3(33.3)$ & $0(0.0)$ & $3(33.3)$ & $6(22.2)$ \\
\hline $\begin{array}{l}\text { Pharyngolaryngeal } \\
\text { pain }\end{array}$ & $1(11.1)$ & $2(22.2)$ & $3(33.3)$ & $0(0.0)$ & $5(18.5)$ \\
\hline $\begin{array}{l}\text { Lymphocyte count } \\
\text { decrease }\end{array}$ & $0(0.0)$ & $0(0.0)$ & $4(44.4)$ & $1(11.1)$ & $5(18.5)$ \\
\hline $\begin{array}{l}\text { Injection site } \\
\text { bruising }\end{array}$ & $1(11.1)$ & $0(0.0)$ & $1(11.1)$ & $3(33.3)$ & $4(14.8)$ \\
\hline $\begin{array}{l}\text { Presence of protein } \\
\text { in urine }\end{array}$ & $1(11.1)$ & $2(22.2)$ & $1(11.1)$ & $1(11.1)$ & $4(14.8)$ \\
\hline Vomiting & $3(33.3)$ & $0(0.0)$ & $1(11.1)$ & $1(11.1)$ & $2(7.4)$ \\
\hline $\begin{array}{l}\text { Urinary tract } \\
\text { infection }\end{array}$ & $2(22.2)$ & $1(11.1)$ & $0(0.0)$ & $1(11.1)$ & $2(7.4)$ \\
\hline $\begin{array}{l}\text { Presence of blood in } \\
\text { urine }\end{array}$ & $1(11.1)$ & $1(11.1)$ & $1(11.1)$ & $0(0.0)$ & $2(7.4)$ \\
\hline $\begin{array}{l}\text { Blood chloride } \\
\text { increase }\end{array}$ & $2(22.2)$ & $1(11.1)$ & $0(0.0)$ & $0(0.0)$ & $1(3.7)$ \\
\hline $\begin{array}{l}\text { Blood potassium } \\
\text { decrease }\end{array}$ & $2(22.2)$ & $0(0.0)$ & $1(11.1)$ & $0(0.0)$ & $1(3.7)$ \\
\hline Influenza & $2(22.2)$ & $0(0.0)$ & $1(11.1)$ & $0(0.0)$ & $1(3.7)$ \\
\hline Lipase increase & $2(22.2)$ & $1(11.1)$ & $0(0.0)$ & $0(0.0)$ & $1(3.7)$ \\
\hline Sinusitis & $2(22.2)$ & $0(0.0)$ & $1(11.1)$ & $0(0.0)$ & $1(3.7)$ \\
\hline
\end{tabular}

Values are shown in descending order of frequency in the total MEDI-528 group.

${ }^{*}$ Consisted of all subjects who received the study drug.

increased in an approximately dose-proportional manner from $13.7 \mu \mathrm{g} / \mathrm{mL}$ to $105.5 \mu \mathrm{g} / \mathrm{mL}$; similar dose proportionality was noted for trough concentrations, which increased from $11.7 \mu \mathrm{g} / \mathrm{mL}$ to $90.4 \mu \mathrm{g} / \mathrm{mL}$. Mean half-life was similar across dose levels (range, 35-38 days).

Comparison of trough concentrations after the first and last doses yielded accumulation index values between 5 and 10 across dose levels. The fluctuation of MEDI-528 concentrations within a dosing interval was small, consistent with the frequency of dosing and half-life (Figure 2).

No anti-MEDI-528 antibodies, defined as antibody titer of $>10$, were detected in any group during study 1 or study 2 .

\section{Pulmonary function}

Pulmonary function was generally unchanged throughout both studies. $\mathrm{FEV}_{1}$ values were comparable among groups at baseline and at the end of the studies (Table 5). In study $1, \mathrm{FEV}_{1}$ percent predicted values were comparable at baseline and end of study (Table 5).
Table 3 Most Frequently Reported Adverse Events in Study 2 (Safety Population*)

\begin{tabular}{lcc}
\hline \multirow{2}{*}{ Event } & \multicolumn{2}{c}{ No. (\%) of Subjects } \\
\cline { 2 - 3 } & $\begin{array}{c}\text { Placebo } \\
(\mathbf{n}=\mathbf{4})\end{array}$ & $\begin{array}{c}\text { MEDI-528 50 } \mathbf{~ m g} \\
\text { (n = 7) }\end{array}$ \\
\hline Blood glucose increased & $0(0.0)$ & $2(28.6)$ \\
Back pain & $1(25.0)$ & $1(14.3)$ \\
Injection site irritation & $1(25.0)$ & $1(14.3)$ \\
Blood bicarbonate increased & $0(0.0)$ & $1(14.3)$ \\
Cyst & $0(0.0)$ & $1(14.3)$ \\
Lipase increased & $0(0.0)$ & $1(14.3)$ \\
Lower respiratory tract infection & $0(0.0)$ & $1(14.3)$ \\
Nuclear MRl abnormal & $0(0.0)$ & $1(14.3)$ \\
\hline
\end{tabular}

Values are shown in descending order of frequency in the MEDI-528 group. $\mathrm{MRI}=$ magnetic resonance imaging.

*Consisted of all subjects who received the study drug.

\section{Asthma control and quality of life}

Asthma control and quality of life results are shown in Table 5. In both studies, a trend toward improvement in the overall mean asthma symptom scores was noted during the treatment period in all subjects compared with baseline values. Overall mean rescue SABA use during both studies was comparable among groups, and overall mean AQLQ scores were comparable between the MEDI528 groups and placebo at baseline and during the study.

In study 1 , fewer subjects having $\geq 1$ asthma exacerbation were observed in the combined MEDI-528 group ( $\mathrm{n}=1$ of 27 ) compared with the placebo group ( $\mathrm{n}=2$ of 9; $P=0.148$ ). The one MEDI-528-treated subject was receiving the lowest dose. The 2 placebo-treated subjects had a total of 4 asthma exacerbation episodes (1 subject had 1 episode; 1 subject had 3 episodes).

In study 2, no asthma exacerbations were reported.

\section{Exercise challenge test}

In study 2, multiple doses of MEDI-528 resulted in a reduction in the mean maximum percentage decrease in $\mathrm{FEV}_{1}$ after exercise as compared to placebo (Table 6). The

Table 4 MEDI-528 Multiple-Dose Pharmacokinetic Parameters in Study 1

\begin{tabular}{ccccc}
\hline Cohort & $\begin{array}{c}\mathbf{C}_{\max } \\
(\boldsymbol{\mu g} / \mathbf{m L})\end{array}$ & $\begin{array}{c}\mathbf{T}_{\max } \\
(\text { day })\end{array}$ & $\begin{array}{c}\mathbf{T}_{\mathbf{1} 2 \mathbf{2}} \\
(\mathbf{d a y})\end{array}$ & $\begin{array}{c}\text { Accumulation } \\
\text { index }^{*}\end{array}$ \\
\hline $\begin{array}{c}0.3 \mathrm{mg} / \mathrm{kg} \\
(\mathrm{n}=9)\end{array}$ & $13.7 \pm 2.7^{\dagger}$ & $\begin{array}{c}3.5 \pm \\
2.1^{\dagger}\end{array}$ & $37.1 \pm 7.5^{\dagger}$ & $5.2 \pm 2.0^{\ddagger}$ \\
$\begin{array}{c}1 \mathrm{mg} / \mathrm{kg} \\
(\mathrm{n}=9)\end{array}$ & $52.1 \pm 33.0$ & $3.7 \pm 2.3$ & $35.0 \pm$ & $9.9 \pm 4.5$ \\
$3 \mathrm{mg} / \mathrm{kg}$ & $105.5 \pm$ & $3.9 \pm 2.6$ & $37.7 \pm 7.5$ & $6.7 \pm 1.8$ \\
$(\mathrm{n}=9)$ & 31.0 & & &
\end{tabular}

Values are mean $\pm S D . C_{\max }=$ maximum concentration; $T_{\max }=$ time to maximum concentration; $T_{1 / 2}=$ half-life.

*Accumulation index was based on trough concentration after first and last dose.

${ }^{+} \mathrm{n}=8$.

${ }^{\ddagger} \mathrm{n}=7$. 


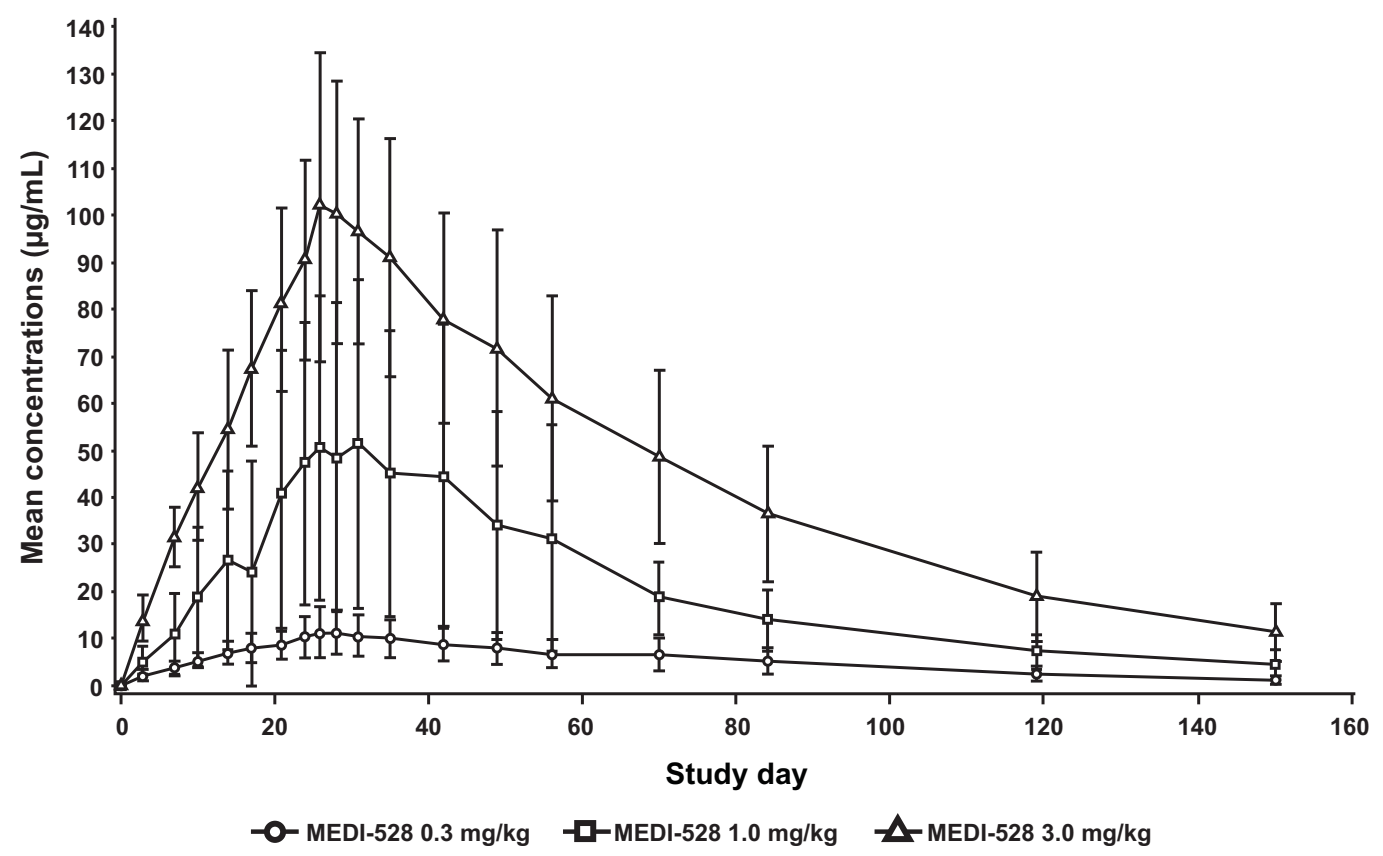

Figure 2 MEDI-528 mean serum concentrations in study 1. Mean maximum concentration after the last dose of $0.3 \mathrm{mg} / \mathrm{kg}$ to $3 \mathrm{mg} / \mathrm{kg}$, respectively, mean half-life, trough concentrations after the first and last doses were measured. Mean concentrations of MEDI-528 increased in a dose-proportional manner and peaked after the last dose of the study drug.

Table 5 Exploratory Analyses in Studies 1 and 2 (Evaluable Population)

\begin{tabular}{|c|c|c|c|c|c|c|}
\hline \multirow[b]{3}{*}{ Parameter } & \multicolumn{4}{|c|}{ Study 1} & \multicolumn{2}{|c|}{ Study 2} \\
\hline & \multirow[b]{2}{*}{ Placebo } & \multicolumn{3}{|c|}{ MEDI-528 } & \multirow[b]{2}{*}{ Placebo } & \multirow[b]{2}{*}{$\begin{array}{c}\text { MEDI-528 } 50 \\
\mathrm{mg}\end{array}$} \\
\hline & & $0.3 \mathrm{mg} / \mathrm{kg}$ & $1 \mathrm{mg} / \mathrm{kg}$ & $3 \mathrm{mg} / \mathrm{kg}$ & & \\
\hline \multicolumn{7}{|l|}{ Pulmonary function } \\
\hline \multicolumn{7}{|l|}{$\mathrm{FEV}_{1}, \mathrm{~L}$} \\
\hline Baseline & $\begin{array}{c}2.8 \pm 0.58 \\
(n=9)\end{array}$ & $\begin{array}{c}2.8 \pm 0.93 \\
(n=9)\end{array}$ & $\begin{array}{c}3.2 \pm 0.73 \\
(n=9)\end{array}$ & $\begin{array}{c}3.4 \pm 0.43 \\
(n=9)\end{array}$ & $\begin{array}{c}3.3 \pm 1.25 \\
(n=2)\end{array}$ & $\begin{array}{c}2.8 \pm 0.56 \\
(n=7)\end{array}$ \\
\hline End of study & $\begin{array}{c}2.9 \pm 0.48 \\
(n=8)\end{array}$ & $\begin{array}{c}2.6 \pm 1.02 \\
(n=9)\end{array}$ & $\begin{array}{c}3.3 \pm 0.67 \\
(n=8)\end{array}$ & $\begin{array}{c}3.6 \pm 0.56 \\
(n=8)\end{array}$ & $\begin{array}{c}3.0 \pm 1.30 \\
(\mathrm{n}=2)\end{array}$ & $\begin{array}{c}2.9 \pm 0.42 \\
(n=5)\end{array}$ \\
\hline \multicolumn{7}{|l|}{$\mathrm{FEV}_{1}, \%$ predicted } \\
\hline Baseline & $\begin{array}{c}89.3 \pm 10.49 \\
(n=9)\end{array}$ & $\begin{array}{c}85.8 \pm 7.95 \\
(n=9)\end{array}$ & $\begin{array}{c}86.0 \pm 12.07 \\
(n=9)\end{array}$ & $\begin{array}{c}93.3 \pm 12.40 \\
(\mathrm{n}=9)\end{array}$ & & \\
\hline End of study & $\begin{aligned} 91.4 & \pm 8.87 \\
(n & =8)\end{aligned}$ & $\begin{array}{c}79.2 \pm \\
11.04 \\
(n=9)\end{array}$ & $\begin{aligned} 90.3 & \pm 9.64 \\
(n & =8)\end{aligned}$ & $\begin{array}{c}99.6 \pm 13.14 \\
(n=8)\end{array}$ & & \\
\hline \multicolumn{7}{|l|}{ Asthma symptom score, overall } \\
\hline Baseline & $\begin{array}{c}1.11 \pm 0.83 \\
(n=6)\end{array}$ & $\begin{array}{c}1.87 \pm 1.70 \\
(n=7)\end{array}$ & $\begin{array}{c}1.37 \pm 1.59 \\
(n=6)\end{array}$ & $\begin{array}{c}0.00 \pm N / A \\
(n=1)\end{array}$ & $\begin{aligned} 1.92 & \pm 1.53 \\
(\mathrm{n} & =2)\end{aligned}$ & $\begin{aligned} 0.93 & \pm 0.82 \\
(\mathrm{n} & =6)\end{aligned}$ \\
\hline Treatment & $\begin{array}{c}0.74 \pm 0.55 \\
(n=7)\end{array}$ & $\begin{aligned} 0.91 & \pm 0.63 \\
(n & =6)\end{aligned}$ & $\begin{array}{c}1.10 \pm 1.49 \\
(n=6)\end{array}$ & $\begin{array}{c}0.13 \pm 0.18 \\
(\mathrm{n}=2)\end{array}$ & $\begin{aligned} 0.91 & \pm 0.07 \\
(\mathrm{n} & =2)\end{aligned}$ & $\begin{aligned} 0.41 & \pm 0.66 \\
(n & =6)\end{aligned}$ \\
\hline $\begin{array}{l}\text { Rescue short-acting } \beta_{2} \text {-agonist use (no. of puffs/day), overall } \\
\text { during study }\end{array}$ & $\begin{aligned} 0.63 & \pm 0.60 \\
(n & =9)\end{aligned}$ & $\begin{aligned} 0.65 & \pm 0.51 \\
(\mathrm{n} & =8)\end{aligned}$ & $\begin{aligned} 0.66 & \pm 0.80 \\
(\mathrm{n} & =8)\end{aligned}$ & $\begin{aligned} 0.02 & \pm 0.04 \\
(\mathrm{n} & =5)\end{aligned}$ & $\begin{aligned} 0.22 & \pm 0.02 \\
(\mathrm{n} & =2)\end{aligned}$ & $\begin{aligned} 0.28 & \pm 0.32 \\
(\mathrm{n} & =7)\end{aligned}$ \\
\hline \multicolumn{7}{|l|}{ AQLQ score, overall } \\
\hline Baseline & $\begin{array}{l}5.56 \pm 1.11 \\
(n=9)\end{array}$ & $\begin{aligned} 5.20 & \pm 0.79 \\
(\mathrm{n} & =9)\end{aligned}$ & $\begin{array}{l}5.73 \pm 0.70 \\
\quad(n=9)\end{array}$ & $\begin{array}{l}5.97 \pm 0.78 \\
\quad(n=9)\end{array}$ & $\begin{array}{l}5.73 \pm 0.11 \\
(n=2)\end{array}$ & $\begin{aligned} 5.75 & \pm 0.65 \\
(n & =7)\end{aligned}$ \\
\hline Day 28 & $\begin{aligned} 5.64 & \pm 0.82 \\
(\mathrm{n} & =9)\end{aligned}$ & $\begin{aligned} 5.68 & \pm 0.66 \\
(\mathrm{n} & =9)\end{aligned}$ & $\begin{aligned} 5.95 & \pm 0.87 \\
(\mathrm{n} & =9)\end{aligned}$ & $\begin{aligned} 6.07 & \pm 0.60 \\
(\mathrm{n} & =9)\end{aligned}$ & $\begin{array}{l}6.22 \pm 0.09 \\
(n=2)\end{array}$ & $\begin{array}{l}5.94 \pm 0.57 \\
(n=7)\end{array}$ \\
\hline
\end{tabular}

Values are mean \pm SD.

$A Q L Q=$ Asthma Quality of Life Questionnaire; FEV 1 = forced expiratory volume in 1 second. 
Table 6 Mean (SD) maximum percentage change in FEV $_{\mathbf{1}}$ after exercise in study 2

\begin{tabular}{lllllllll}
\hline & Baseline & $\boldsymbol{P}$ Value & Day $\mathbf{2 8}$ & $\boldsymbol{P}$ Value & Day 56 & $\boldsymbol{P}$ Value & Day 150 & $\boldsymbol{P}$ Value \\
\cline { 2 - 7 } MEDI-528 $(\mathrm{n}=7)^{*}$ & $-22.20(4.38)$ & 0.62 & $-6.49(11.73)$ & 0.22 & $-1.40(2.27)$ & 0.17 & $-5.04(3.91)$ & 0.52 \\
Placebo $(\mathrm{n}=2)$ & $-20.20(4.16)$ & & $-12.60(1.53)$ & & $-20.10(7.41)$ & & $-15.20(15.48)$ \\
\hline
\end{tabular}

*For day $150, \mathrm{n}=6$. $P$ values are based on two-sample $t$ test between placebo and MEDI-528 groups.

mean absolute maximum decline in $\mathrm{FEV}_{1}$ at study day 56 was $-0.04 \mathrm{~L}$ for the MEDI-528 group compared with -0.60 $\mathrm{L}$ for the placebo group $(P<0.01)$. Differences at all other data points did not achieve statistical significance (data not shown). Time to return to $90 \%$ of baseline $\mathrm{FEV}_{1}$ following exercise challenge was shorter during the screening period prior to dosing with study drug and at all subsequent study days for the MEDI-528 group as compared with placebo. Furthermore, the time to return to $90 \%$ of baseline $\mathrm{FEV}_{1}$ improved in the MEDI-528 group at study days 28 and 56, while there was no improvement in the placebo group. A post hoc analysis showed that 6 of 7 MEDI-528-treated subjects were responders at study day 28, 7 of 7 at day 56 , and 6 of 6 at day 150. There were no placebo-treated responders at days 28 and 56, and there was 1 responder at day 150 (Figure 3).

\section{Discussion}

In both studies, subjects tolerated multiple SC doses of MEDI-528, with AE, severe AE and SAE rates similar to placebo-treated subjects. No subjects developed antiMEDI-528 antibodies. MEDI-528 exhibited linear PK, with peak and trough concentrations increasing in an approximately dose-proportional manner over the dose range studied. The half-life values (35-38 days) were consistent with those observed in the high-dose groups of the single-dose SC study of healthy volunteers [24],

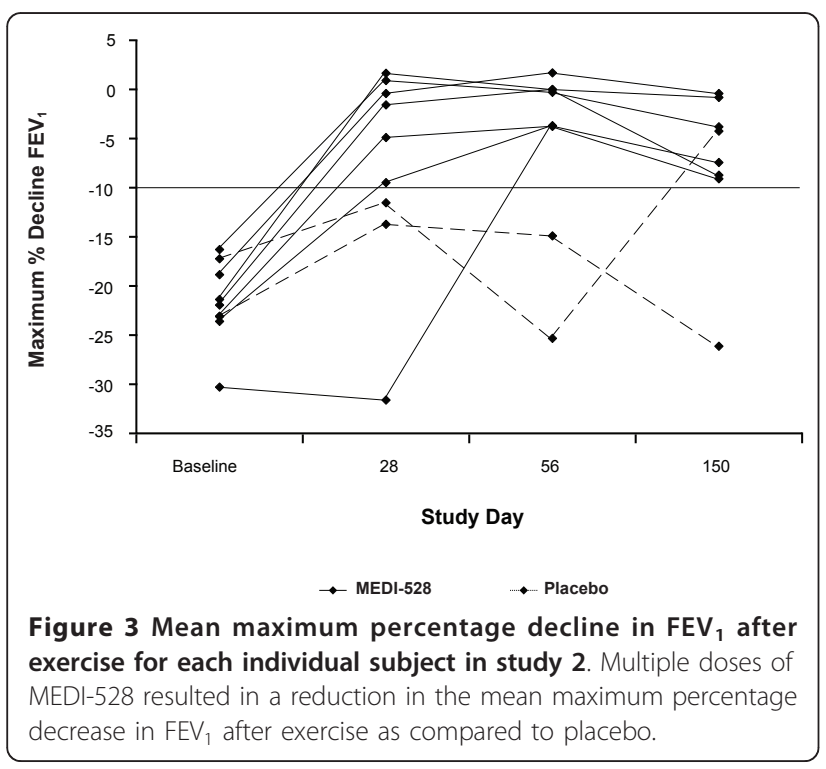

namely, the $3-\mathrm{mg} / \mathrm{kg}$ (half-life, 44 days) and $9-\mathrm{mg} / \mathrm{kg}$ (half-life, 33 days) doses. In addition, these results are in accord with findings from the 2 studies conducted in healthy volunteers [24]. In those studies, MEDI-528 had an acceptable safety profile, with no SAEs or deaths reported.

Throughout study 1, pulmonary function was essentially unchanged and SABA use was comparable among groups. Overall, asthma symptom scores showed a trend toward improvement in all subjects. A trend toward fewer subjects having $\geq 1$ asthma exacerbation was observed in MEDI-528-treated subjects in study 1 compared with placebo-treated subjects. This finding is of unclear significance as blocking IL-9 may result in a reduction in AHR [13,14] and AHR has not been clearly related to asthma exacerbations.

Although the actions of IL-9 are not fully understood, IL-9 is believed to play an important role in the trafficking and function of mast cells $[15,16]$. Local IL-9 production from inflammatory cells would theoretically result in the recruitment and differentiation of mast cell progenitors from the bone marrow to the lung. Blocking IL-9 would therefore not be expected to have an immediate clinical effect, but this would rather be dependent on the loss of resident mast cells in the tissue.

The results of study 2 are intriguing in that they suggest that blocking IL-9 with MEDI-528 may have an effect on EIB, which is dependent on mast cell degranulation [19]. The maximum effect of MEDI-528 was seen at study day 56 , which would be consistent with a later onset of action. Future studies should consider that a period of chronic dosing may be required before seeing maximum clinical effect. Conclusions from study 2 are unfortunately limited in that it was prematurely halted.

Because of the small sample size in both studies, firm conclusions regarding the clinical activity of MEDI-528 cannot be drawn from these results. The potential benefits of MEDI-528 observed in both studies should be interpreted with caution as these studies were also limited by the mild disease severity of the study population.

\section{Conclusions}

In conclusion, prior and current results suggest that MEDI-528 has acceptable safety and tolerability profiles and provide evidence of clinical activity in mild to moderate asthmatics. Further studies are warranted to assess 
the clinical efficacy of MEDI-528 for treating patients with inadequately controlled asthma.

\begin{abstract}
Acknowledgements
The authors thank the investigators of the MEDI-528 Clinical Trials Group: Louis-Philippe Boulet, MD, Institut de Cardiologie et de Pneumologie de I'Université Laval, Hôpital Laval, Québec City, Québec, Canada; Charles Fogarty, MD, Spartanburg Medical Research, Spartanburg, SC, USA; Gail Gauvreau, PhD, McMaster University, Hamilton, Ontario, Canada; Harold Kaiser, MD, Clinical Research Institute, Minneapolis, MN, USA; Catherine Lemiere, MD, MSch, Hôpital du Sacré-Coeur de Montréal, University of Montréal, Montréal, Québec, Canada; Shari Brazinsky, MD, Institute of HealthCare Assessment, San Diego, CA, USA; Anjuli Nayak, MD, Sneeze, Wheeze \& Itch Associates, Normal, IL, USA; and Phillip Korenblat, MD, Clinical Research Center, St. Louis, MO, USA. The authors also acknowledge Vali Sevastita, MS, formerly with Medlmmune, LLC, and Miriam Gitler, PhD, Medlmmune, LLC, for their medical writing support.
\end{abstract}

\section{Author details}

'Medlmmune, LLC, Gaithersburg, MD, USA. ${ }^{2}$ North Carolina Clinical Research, Raleigh, NC, USA. ${ }^{3}$ Northeast Medical Research Associates, North Dartmouth, MA, USA. ${ }^{4}$ Colorado Allergy \& Asthma Centers PC, Denver, CO, USA. ${ }^{5}$ Current address: UCB Biosciences, Inc., Raleigh, NC, USA.

\section{Authors' contributions}

$\mathrm{CLF}, \mathrm{SDM}$, and DP were involved in the collection of data and interpretation of the results; JMP, CKO, CL, GJR, WIW, BW, and NAM were involved in the design of the study, analysis of the data, and interpretation of the results; all authors critically reviewed and revised the manuscript and approved the final version.

\section{Competing interests}

CLF, SDM, and DP received research funding from Medlmmune, LLC, for the conduct of these studies. JMP, CKO, CL, GJR, WIW and NAM are employees of Medlmmune, LLC. BW was an employee of Medlmmune, LLC, at the time of the study and manuscript submission. These studies were sponsored by Medlmmune, LLC.

Received: 8 June 2010 Accepted: 28 February 2011 Published: 28 February 2011

\section{References}

1. Eder W, Ege MJ, von Mutius E: The asthma epidemic. N Engl J Med 2006, 355:2226-2235.

2. Current asthma prevalence percents by age, United States: National health interview survey, 2006. 2008 [http://www.cdc.gov/asthma/nhis/06/ data.htm].

3. Bateman ED, Boushey HA, Bousquet J, Busse WW, Clark TJ, Pauwels RA, Pedersen SE, GOAL Investigators Group: Can guideline-defined asthma control be achieved? The Gaining Optimal Asthma ControL study. Am J Respir Crit Care Med 2004, 170:836-844.

4. Wiener Z, Falus A, Toth S: IL-9 increases the expression of several cytokines in activated mast cells, while the IL-9-induced IL-9 production is inhibited in mast cells of histamine-free transgenic mice. Cytokine 2004, 26:122-130.

5. McNamara PS, Flanagan BF, Baldwin LM, Newland P, Hart CA, Smyth RL: Interleukin 9 production in the lungs of infants with severe respiratory syncytial virus bronchiolitis. Lancet 2004, 363:1031-1037.

6. Gounni AS, Nutku E, Koussih L, Aris F, Louahed J, Levitt RC, Nicolaides NC, Hamid Q: IL-9 expression by human eosinophils: regulation by IL-1beta and TNF-alpha. J Allergy Clin Immunol 2000, 106:460-466.

7. Stassen M, Arnold M, Hultner L, Muller C, Neudorfl C, Reineke T, Schmitt E. Murine bone marrow-derived mast cells as potent producers of IL-9: costimulatory function of IL-10 and kit ligand in the presence of IL-1. J Immunol 2000, 164:5549-5555.

8. Nicolaides NC, Holroyd K, Ewart SL, Eleff SM, Kiser MB, Dragwa CR, Sullivan CD, Grasso L, Zhang LY, Messler CJ, Zhou T, Kleeberger SR, Buetow KH, Levitt RC: Interleukin 9: a candidate gene for asthma. Proc Natl Acad Sci USA 1997, 94:13175-13180.
9. Temann UA, Geba GP, Rankin JA, Flavell RA: Expression of interleukin 9 in the lungs of transgenic mice causes airway inflammation, mast cell hyperplasia, and bronchial hyperresponsiveness. J Exp Med 1998, 188:1307-1320.

10. Temann UA, Ray P, Flavell RA: Pulmonary overexpression of IL-9 induces Th2 cytokine expression, leading to immune pathology. J Clin Invest 2002, 109:29-39.

11. Hauber HP, Bergeron C, Hamid Q: IL-9 in allergic inflammation. Int Arch Allergy Immunol 2004, 134:79-87.

12. van den Brule S, Heymans J, Havaux X, Renauld JC, Lison D, Huaux F, Denis O: Profibrotic effect of IL-9 overexpression in a model of airway remodeling. Am J Respir Cell Mol Biol 2007, 37:202-209.

13. Cheng G, Arima M, Honda K, Hirata H, Eda F, Yoshida N, Fukushima F, Ishii Y, Fukuda T: Anti-interleukin-9 antibody treatment inhibits airway inflammation and hyperreactivity in mouse asthma model. Am J Respir Crit Care Med 2002, 166:409-416.

14. Kung TT, Luo B, Crawley Y, Garlisi CG, Devito K, Minnicozzi M, Egan RW, Kreutner W, Chapman RW: Effect of anti-mlL-9 antibody on the development of pulmonary inflammation and airway hyperresponsiveness in allergic mice. Am J Respir Cell Mol Biol 2001, 25:600-605.

15. Williams CM, Galli SJ: Mast cells can amplify airway reactivity and features of chronic inflammation in an asthma model in mice. J Exp Med 2000, 192:455-462.

16. Jones TG, Hallgren J, Humbles A, Burwell T, Finkelman FD, Alcaide $P$, Austen KF, Gurish MF: Antigen-induced increases in pulmonary mast cell progenitor numbers depend on IL-9 and CD1d-restricted NKT cells. J Immunol 2009, 183:5251-5260.

17. Lee TH, Nagy L, Nagakura T, Walport MJ, Kay AB: Identification and partial characterization of an exercise-induced neutrophil chemotactic factor in bronchial asthma. J Clin Invest 1982, 69:889-899.

18. Pliss LB, Ingenito EP, Ingram RH Jr, Pichurko B: Assessment of bronchoalveolar cell and mediator response to isocapnic hyperpnea in asthma. Am Rev Respir Dis 1990, 142:73-78.

19. Van Schoor J, Pauwels R, Joos G: Indirect bronchial hyper-responsiveness: the coming of age of a specific group of bronchial challenges. Clin Exp Allergy 2005, 35:250-261.

20. Shimbara A, Christodoulopoulos P, Soussi-Gounni A, Olivenstein R, Nakamura Y, Levitt RC, Nicolaides NC, Holroyd KJ, Tsicopoulos A, Lafitte JJ, Wallaert B, Hamid QA: IL-9 and its receptor in allergic and nonallergic lung disease: increased expression in asthma. J Allergy Clin Immunol 2000, 105:108-115.

21. Ying $S$, Meng $Q$, Kay $A B$, Robinson DS: Elevated expression of interleukin9 mRNA in the bronchial mucosa of atopic asthmatics and allergeninduced cutaneous late-phase reaction: relationships to eosinophils, mast cells and T lymphocytes. Clin Exp Allergy 2002, 32:866-871.

22. Toda M, Tulic MK, Levitt RC, Hamid Q: A calcium-activated chloride channel (HCLCA1) is strongly related to IL-9 expression and mucus production in bronchial epithelium of patients with asthma. J Allergy Clin Immunol 2002, 109:246-250.

23. Erpenbeck VJ, Hohlfeld JM, Volkmann B, Hagenberg A, Geldmacher H, Braun A, Krug N: Segmental allergen challenge in patients with atopic asthma leads to increased IL-9 expression in bronchoalveolar lavage fluid lymphocytes. J Allergy Clin Immunol 2003, 111:1319-1327.

24. White B, Leon F, White W, Robbie G: Two first-in-human, open-label, phase I dose-escalation safety trials of MEDI-528, a monoclonal antibody against interleukin-9, in healthy adult volunteers. Clin Ther 2009, 31:728-740.

25. National Heart, and Blood Institute. National Institutes of Health. National Asthma Education and Prevention Program: Expert Panel Report 3 (EPR-3): Guidelines for the Diagnosis and Management of Asthma-Summary Report 2007. J Allergy Clin Immunol 2007, 120:S94-138.

26. Weiler JM, Bonini S, Coifman R, Craig T, Delgado L, Capao-Filipe M, Passali D, Randolph C, Storms W, Ad Hoc Committee of Sports Medicine Committee of American Academy of Allergy, Asthma \& Immunology: American Academy of Allergy, Asthma \& Immunology Work Group report: exercise-induced asthma. J Allergy Clin Immunol 2007, 119:1349-1358.

27. Crapo RO, Casaburi R, Coates AL, Enright PL, Hankinson JL, Irvin CG, Maclntyre NR, McKay RT, Wanger JS, Anderson SD, Cockcroft DW, Fish JE, Sterk PJ: Guidelines for methacholine and exercise challenge testing- 
1999. This official statement of the American Thoracic Society was adopted by the ATS Board of Directors, July 1999. Am J Respir Crit Care Med 2000, 161:309-329.

28. Juniper EF, Buist AS, Cox FM, Ferrie PJ, King DR: Validation of a standardized version of the Asthma Quality of Life Questionnaire. Chest 1999, 115:1265-1270.

29. Pepys J: Skin testing. Br J Hosp Med (Lond) 1975, 14:412-417.

30. Miller MR, Hankinson J, Brusasco V, Burgos F, Casaburi R, Coates A, Crapo R, Enright P, van der Grinten CP, Gustafsson P, Jensen R, Johnson DC, Maclntyre N, McKay R, Navajas D, Pedersen OF, Pellegrino R, Viegi G, Wanger J, ATS/ERS Task Force: Standardisation of spirometry. Eur Respir J 2005, 26:319-338.

\section{Pre-publication history}

The pre-publication history for this paper can be accessed here: http://www.biomedcentral.com/1471-2466/11/14/prepub

doi:10.1186/1471-2466-11-14

Cite this article as: Parker et al: Safety profile and clinical activity of multiple subcutaneous doses of MEDI-528, a humanized anti-

interleukin-9 monoclonal antibody, in two randomized phase $2 a$ studies in subjects with asthma. BMC Pulmonary Medicine 2011 11:14.

\section{Submit your next manuscript to BioMed Central} and take full advantage of:

- Convenient online submission

- Thorough peer review

- No space constraints or color figure charges

- Immediate publication on acceptance

- Inclusion in PubMed, CAS, Scopus and Google Scholar

- Research which is freely available for redistribution

Submit your manuscript at www.biomedcentral.com/submit 